This is the Accepted Version of the forthcoming article 'Dimensions of Transnationalism' which will be published by Palgrave Macmillan in Feminist Review; Issue 117: http://www.palgravejournals.com/fr/index.html

Accepted Version downloaded from SOAS Research Online: http://eprints.soas.ac.uk/22468/

'Dimensions of Transnationalism' - forthcoming in Feminist Review; 117

Alyosxa Tudor - Centre for Gender Studies, SOAS University of London

Abstract

This article identifies and analyses links between conceptualisations of trans-gender and trans-national and aims for a critical redefinition of political agency. Through an examination of theories on transing, passing and performativity in queer-, trans-, and transnational feminist knowledge production and illustrated by discursive examples from transgender communities and Romanian migrant communities, I call for a conceptualisation of entangled power relations that does not rely on fixed, pre-established categories but defines subjectivity through risk in political struggle.

I suggest that 'transing' the nation and 'transing' gender could be thought as critical moves for a radical deconstruction of gendered and national belonging. Rather than provide a static definition of the term 'transnationalism', the article explores potentials and limits of going beyond 'the national' and 'gender' and intervenes in forms of minority nationalism that reproduce racism, sexism, heteronormativity and gender binary as the norm of Western national belonging. In particular, building on Jasbir Puar's conceptualisation of homonationalism, the article shows how forms of nationalism in Western transgender and migrant communities rely on a combination of heteronormative binary gendering and the exertion of racism. While a conventionalised approach to transnationalism defines the term as a political strategy based on transnational politics, I play with suggesting different dimensions of transnationalism: it could mean 'transgender nationalism'; the 'assimilation of transgendered persons to the Western nation'; or 'cross-border-nationalism', a form of nationalism often established in migrant communities that constructs the diaspora as a nationalist extension of the homeland. My focus, therefore, is on analysing privilegings, contradictions and ambivalences in gendering, racialising and nationalising ascriptions of (non)belonging.

Overall, and as an alternative to romanticized knowledge productions of crossing national and gendered borders, I suggest a power-sensitive epistemological and methodological shift in thinking 
entangled power relations, belonging and subjectivity in trans_national feminist knowledge productions.

Keywords: transfeminism, transgender, transnationalism, Romanian migrant communities, passing, intersectionality

\section{Dimensions of Transnationalism}

Intro

This article explores what difference it would make to feminist political solidarity not only to consider 'transnationalism' as a question of mobility across borders or a form of movement and solidarity beyond nation states, but also as a term that names two forms of minority nationalism (transgender nationalism and cross-border-nationalism) and exposes their logics.

As I aim to show, 'transnationalism' could mean a 'political strategy based on transnational politics', but moreover, building an analogous term to Jasbir Puar's conceptualization of 'homonationalism' (2007), it could mean the assimilation of transgendered persons to the nation. In a third level of meaning, 'transnationalism' could refer to 'cross-border-nationalism' or 'diasporic nationalism' - a form of nationalism often established in migrant communities that constructs the diaspora as nationalist extension of the homeland. In both 'transgender nationalism' and 'cross-border-nationalism' the reproduction of repro- and heteronormative binary gendering plays a crucial role in consolidating fantasies and possibilities of national belonging.

My approach starts with a critical discussion of concepts of passing and being read. Passing, in the definition I am advocating here, is making oneself readable as privileged from a discriminated positioning. It is about provisionally undermining the perceptibility of 
'structural difference' (Ahmed 1999b: 93). Being read is not the same as passing, but is part of the complex of not/passing, and can lie transversal to the self-conception of one's own performance. Mis/Readings, therefore, rely on conventionalized, situated and contextual habits of reading, seeing and perceiving.

Furthermore, I elaborate on the concept of transing. I define transing as a critical move rooted in specific political movements. It means to go beyond a certain category; to question a category; to deconstruct a category. If transing gender means going beyond gender, one could say in consequence that even the very existence of gender as category is problematic. Similar thoughts concerning 'the national' can be found in transnational feminist approaches (see for example Campt 2011).

In Part II of the article, I relate the readings of passing/being read and transing that I conduct in Part I to strategies of hegemonic co-optation of certain marginalized groups, on the one hand, and their desire to belong to the dominant norm at any cost on the other hand. With my analyses of these examples I aim to show that in Western/European contexts, ascriptions of migration, racialisation and gendering rely on each other in specific ways and a problematic normative nexus of racialisation and binary gendering is reproduced in forms of minority nationalism. In accordance to my claim to conceptualise passing and being read in intersectional terms, I call for an intersectional response to these forms of minority nationalism and their effects and strategies.

My analysis plays with dimensions of 'transnationalism' and puts different feminist anti-nationalist strands into critical dialogue. The term 'dimensions' indicates that I am interested in analysing layers, thinkabilities and limits in meaning making processes in relation to 'transnationalism'. It is not my aim to replace the conventionalised term, but rather to juggle different meanings in order to engage with the work of the 'trans' and the 'national/ism' in it. Rather than provide a static definition of the term 'transnationalism', the article explores potentials and limits of going beyond 'the national' and 'gender' and intervenes in forms of minority nationalism that reproduce racism, sexism, heteronormativity and gender binary as the norm of Western national belonging. To do this, I analyse 
theoretical and political terrains of engagement where 'transing' the nation and 'transing' gender are conceptualized and highlight how these two dimensions can be thought about together. I revisit queer/trans feminist theoretical interventions on transing, passing and performativity and aim to elaborate possibilities of intervention that disrupt nationalist and racist logics of gender binaries. In conclusion, I suggest an epistemological and methodological shift for transnational feminist approaches to intersectionality ${ }^{\mathrm{iii}}$, and offer a way of re-thinking belonging, discrimination and privileging in transnational feminism through solidarity and risk in political struggle.

\section{Part I: Theories}

\section{Passing and Being Read}

I am read as a dyke and/or as a transperson in specific contexts, in different moments and places. In others I am read as a teenage boy, which also potentially transes me. When I am read as a woman (indeed always as a gender deviant woman), my age is read in a way corresponding to the conventionalized data in my papers. When I am read as male it always reduces the age people read. When I am read as a teenage boy, people mostly read me also as migratised. When I am read as a gender deviant woman, people mostly read me as non-migrant. When I am read as migratised, I mostly get read as male. When I am read as non-white, I am never read as Black, but as migratised and therefore PoC. In Kreuzberg, Berlin, where I have considered myself to be at home for a while, being read as migratised, in most cases, means being read as migratised=Muslim=PoC, as being a migrant there means being a Muslim in a hegemonic understanding. In other words, despite my being privileged through racism, sometimes I am read as Person of color, namely when I am read as migratised and this ascription of migration becomes a racialisation.

Do these readings turn me into a boy? Into a teenager? A Muslim? A non-migrant? A Person of color? Discriminated by racism ? $^{\text {iv }}$ 
In this article, I want to bring conceptualisations of passing and being read not only together with forms of transing (going beyond established categories), but also with discussions of complex misreadings, performative becomings and ambivalent privilegings within the process of social ascription. Therefore, I introduce queer-feminist ideas of passing and discuss their contribution to thinking intersectional privilegings and discriminations in relation to subjectivation and to processes of becoming socially positioned through power relations.

Both Sara Ahmed and Judith Butler criticise approaches that assume that passing references a 'real' that is abandoned or that equates practices of reading with visual evidence (Ahmed 1999b; Butler 1993). Ahmed emphasises that conceptualisations of passing are problematic when they reproduce the idea of an essential self that is misrepresented, understand passing as automatically transgressive or assume an equivalence between two binarised positionings (Ahmed 1999b). Jasbir Puar follows Butler in highlighting that, in the process of perceiving and ascribing persons, reading and seeing often get collapsed into each other. By way of this, the socially learned ability (that relies on normative ableism) to deduce conventionalized meanings from habits of seeing is naturalized (see Puar 2007: 183).

In line with these interventions, the concept of passing I am interested in here is not about performing an identity that does not correspond with one's own original and essential identity, but is about subverting momentarily and contextually the perceptibility of structural difference. Moreover, I want to investigate the process of passing in relation to the process of being mis/read in order to discuss mis/readings and reactions to mis/readings in the second part of this article.

Ahmed distinguishes between discriminated and privileged forms of passing and subjectivation by defining risks and danger of death that come (or do not come) with passing: "Would one worry, would one fear being caught out, if one did not already perceive oneself to be passing for white? Would there be danger, would there be death?" (Ahmed 1999b: 93; emphasis Ahmed). She elaborates on the fundamental distinction of essential 
and structural difference (ibid.) where structural difference is the power difference between binarised social positionings ${ }^{\vee}$ and plays a role in the process of passing:

The difference between the black subject who passes as white and the white subject who passes as white is not then an essential difference that exists before passing. Rather, it is a structural difference that demonstrates that passing involves the re-opening or re-staging of a fractured history of identifications that constitutes the limits to a given subject's mobility (ibid.; emphasis Ahmed).

This means, in a certain sense, that every performance of whiteness is a 'passing' as white. But of course there are differences between the passing as white from a white social positioning and the passing as white from a Black social positioning. Passing has, at any one time, a "history of self-identification and identification by others" (ibid.).

Ahmed begins her elaborations on passing with a reading of Butler's Gender Trouble and Bodies that Matter (Butler 2007 [1990], 1993). She explicates that Butler underlines in Bodies that Matter why Gender Trouble is not an invitation to a power-evasive play with gendering. Her reading brings to the point what is important about Butler's conceptualisation of performativity for my understanding of social positioning and critical positioning (see Tudor 2014): it is not about fixed identities, but it is just as little about simply putting off any 'structural difference' (Ahmed 1999b: 93) in voluntaristic acts.

Conceptualizations of performativity have a strong potential for the argument I aim to make here. Butler criticizes approaches which state that gender is irrelevant, because it can be subverted any time by practices like cross-dressing: "gender is constructed through relations of power and, specifically, normative constraints that not only produce but also regulate various bodily beings" (Butler 1993: x; emphasis mine). Butler warns against the assumption that gendered positionings can be taken out of the closet every morning independently from their entanglement with power relations: "Such a willful and instrumental subject, one who decides on its gender, is clearly not its gender from the start and fails to realize that its existence is already decided by gender" (ibid.; emphasis Butler). 
The question, "Would there be danger, would there be death?" (Ahmed 1999b: 93) is therefore not only relevant for passing, but for any form of negotiation of power relations and, in my opinion, for processes of subjectivation in and through political struggles. From which positionings is fighting against power relations connected to danger and death? How then are social positionings constructed through the exposure to danger and death?

In relation to gender, passing becomes complicated through a questioning of binary gendering as its starting point. In the story I have shared here, this means I understand my gendered passing or being read not as the one of a 'woman' who passes as a (younger) 'man', and neither as that of a 'transman' who passes as a 'cisman', but as that of a transing person who passes as unambiguously gendered in situations that request the performance of (one side of) binary gendering (and who often fails). Moreover, in some cases, it seems to be impossible with a conventionalized repertoire of possibilities of perception to recognize several structural discriminations simultaneously. This means, in reverse, that processes of ascribing make some positionings appear hypervisible and some positionings get constructed as mutually exclusive, while some even get totally erased. My example of being read and misread ambivalently in connection to gender and migration shows that this is connected to a very complex process of shifting between discriminated and privileged positionings.

"We are all trans" (Halberstam 1994: 226) ${ }^{\mathrm{vi}}$ and 'we' are all in the process of passing in different ways. However, the reflection of these processes rely fundamentally on the perception, reflection and politicization of the risks, through which these processes are defined. "But passing is not becoming" (Ahmed 1999b: 96), explicates Ahmed. According to her, passing is an ambivalent process that does not turn the passing subject into a being subject. However, passing does not pass without a trace, but ascribes itself as a part of an always newly written history in the process of subjectivation.

It is my point here that passing and mis/reading - making oneself readable and being read in relation to conventionalized social positionings (dimensions that do not necessarily have to coincide) - can become contradictory through specific intersectional power relations. 
This means, if there are only either/or registers available, discriminations get constructed as mutually exclusive. Or, a switching effect is produced: in my case this means being constructed as a migratised, male youth in one moment and context and, in the next moment and context, as a non-migrant lesbian and, in the next, as a gender deviant woman - cross-fadings of conventionalized reading habits in an infinite loop. What this shows us is that the 'real' under the mis-reading is itself not stable. Nevertheless, it becomes clear that social positionings are not simply undone by (repeated) mis-readings (as I don't become a Muslim teenage boy or a non-migrant woman despite being repeatedly read as such). There arises a paradox of perception and non-perception, of hypervisibility and denial of structural difference. The rules of this are mostly hegemonic. Passing is a strategy that adopts those rules from a discriminated perspective and uses them in an oppositional way.

In the discussion of my own experience, I am concerned explicitly with the deperception of intersectional structural discriminations through conventional practices of perception. Importantly, this 'transing' of stable positionings is about intersectional social readings that also suggest that an intersectional response is necessary. It complicates concepts of passing and performative becoming both in terms of practices of reading/being seen but also in terms of essences.

When I am not being read as a migratised ${ }^{\text {vii }}$ male teenager, but as a gender-deviant adult woman, I usually do not get migratised, as in Western European hegemonic understandings of gender deviance is imagined as mutually exclusive to migratisation.

Do these conventionalised readings then turn me into a non-migrant or into a Muslim boy? Or do they turn migratised, gender-transing persons into abjects - non-readable within the conditions of legibility of migratisation and gendering? What do these projections have to do with me, what effect do they have on my self-constructions and on the possibility to feel represented in discourses and to be able to critically position myself?

It becomes clear that transphobia, lesbo-/queerphobia and migratism complicate my potential legibility as unambiguous. This has effects on my possibilities of passing as privileged by migratism or as binary gendered or as straight. Migratised womanhood gets 
inseparably connected to a sexist, heteronormative and bigendering culturalised image of 'traditional femininity'. My argument, therefore, is that legibilities and the possibility of performing social positionings get complicated, cancel each other out or become even impossible through intersectional discriminations.

But passing as privileged by racism, passing as privileged by migratism ${ }^{\text {vii }}$ and passing as privileged by sexism, for example, do not function in a parallel way and cannot be analogised directly. Thus, thinking about intersectionalities of racist, sexist, trans- and lesbophobic discrimination together and through each other complicates conceptualisations of passing and being read necessarily more than monolithic approaches. This im/possibility, abjectification and in-betweeness that is constructed through ambivalent readings and ascriptions does not only get reproduced constantly in mainstream contexts, but also in migratised communities and family contexts and, likewise, in non-migrant queer, trans and feminist contexts, as they often implicitly conceptualize trans/dyke/lesbian/queer and migratised as mutually exclusive. And, it is especially migrant communities and ideas of transgender emancipation that I want to revisit in the following to investigate tendencies of assimilation to dominant ideas of belonging.

\section{Transing: Thinking together Transnational Feminism and Transgender Studies}

From one category, one label to another, the only way to survive is to refuse. (Trinh 2010: 48)

What is important to me in the discussion I want to initiate here, is that mis/readings of belonging and non-belonging and ascriptions of ambivalence and in-betweeness are complex and contradictory. Therefore, making sense of these processes in a responsible way needs a reflective thinking together of intersectional power relations. Politicising this in social movements requires careful consideration of performativity, passing, self-appellation and privileging. One way to think beyond stable and pregiven forms of gendered and national belonging is to question the very existence of gender and nation as categories. Transing could do the work of going beyond categories, deconstructing categories. In the following, I therefore bring insights from transnational feminism together with transgender 
studies and explore their shared investment in 'trans' as potential for an intersectional approach on gender, racialization and nation that goes beyond fixed categories. With this in mind, I elaborate an understanding of 'trans_feminism' that builds upon approaches within transgender feminism and transnational feminism which question essentialised pre-given categories of gender and nation.

Many strands in feminism have always been invested in deconstructing gender. Finn Enke, for example, defines 'trans' as constitutive of gender studies and feminism (Enke 2012a: 2), and thinks of "feminism as a transgender phenomenon" (ibid.). Enke underlines: "Some version of gender self-determination and resistance to binary gender norms and oppressions has always been central to feminism" (ibid.). For Enke, 'transfeminism' is a vision that opens up 'feminist' and 'trans' for each other and connects them to various other approaches "by participants whose names we may not even yet know" (Enke 2012a: 3).

Susan Stryker et al. understand 'transing' as a critical crossing of categories: "Trans: -gender, -national, -racial, -generational, -genic, -species" (Stryker et al. 2008: 11). Trystan Cotton, connects in his edited volume Transgender Migrations (2012) geopolitical perspectives with transgender politics, asking how can various "transit/ions" (ibid.: 2) "national, cultural, economic, and geographical migrations" be thought together with "transing gender" (ibid.)?

Building on these interventions that stress the importance of 'trans-ing' or 'going beyond' as central, I argue for a change of perspective in the conceptualisation of intersectional categories. In my view, 'transing' has the potential to shift our focus away from categories and towards power relations, but it is also important to highlight ways in which some conceptualisations of 'trans' reproduce categories instead of deconstructing them. While transing can do the work of creating solidarity and at the same time challenge borders and boundaries (with respect to nation and migration), it works less well in respect of 'race'. 'Trans' in relation to some categories, such as race for example, is problematic, and ambivalences and ruptures in relation to race have to be grasped in different dimensions ${ }^{\text {ix }}$. 
The questioning of categorisations and the effort to make thinkable different dimensions of 'going beyond' is a central claim in transnational feminism. As Shohat (2001) so carefully explicates, transnational feminism is about solidarity, political alliances and community building. 'Transnationalism' is widely used as a term for politics based on transnational networks and social movements that transgress national borders. Similarly, transnational feminism tries to extend solidarity and political struggles beyond nation states. In a broad move of crossing over, transnational feminism connects analyses of colonialism, racism, diaspora and global division of labour with critiques of hegemonic knowledge productions and intervenes in approaches that conceptualise gender without geopolitical and postcolonial restrictions (see for example Alexander und Mohanty 1997; Brah 1996; Campt 2011; Frankenberg und Mani 1993; Grewal und Kaplan 2006; Mendoza 2002; Mohanty 2003a; Shohat 2001, 2002; Trinh 1989).

Breny Mendoza engages with the meaning of 'transnational' in transnational feminism and asks what benefits there are for understanding power dynamics in relation to globalisation/'the Global', transnational capitalism, Third World/First World divisions, political economics, and feminist ethnocentrism (Mendoza 2002). Mendoza calls for a focus on feminisms that are not constructed as co-dependent on Western feminism (Mendoza 2002: 320) and identifies the "gaps between the intentions [...] and outcomes of transnational feminist mobilizations." (ibid.: 328). Another meta-reflection on 'transnational feminism' is offered by Tina Campt, who questions the meaning of the term 'transnational': "What is the 'trans' in transnational feminist practice, and what is the work of the national therein?" (Campt 2011: 131). Campt insists that there are no ultimate answers to these questions and calls for ongoing rethinking of connections, ambivalences and tensions of global and local dimensions of power, of the specific and the universal (ibid.: 134). She criticises 'the national' as a too often unquestioned category and finds transnational approaches problematic that reproduce 'the national' as stable common ground.

One of the difficulties of transnational feminist approaches is to go beyond national/ist paradigms and at the same time reflect on the hierarchisation of nations and 
national belonging (see Bhanji 2012: 161; Mendoza 2002: 313). This also means that (Western) transnational feminist attempts to de-center Eurocentric/Western feminist knowledge productions without re-centering the West and Europe are fragile. This idea reveals one of the key problems of a Western transnational feminist approach: it remains concerned with the division of 'the West and the Rest' (see Hall 2006) and thereby often reproduces this binary. Feminist theorists in the Global South and/or working on the Global South challenge this reproduction of Eurocentrism within transnational feminism while questioning ideas of non-Western purity (see for example Al-Ali 2009; Herr 2014; Mama 2004, 2011; Sangtin Writers Collective und Nagar 2006; Sayegh 2015; Wilson 2012).

One of the assumptions of Western/European nationalism is the automatized nexus of home, nation and racialisation (see for example Ahmed 1999a; Bhanji 2012; Aizura 2006; El-Tayeb 1999; Mohanty 2003b; Wright 2004; Yuval-Davis 1993). In the long 19th century, the colonial competition of the emerging European nations became one of the central themes of European identification and national identification as European (El-Tayeb 2001: 61). The idea of supremacy in relation to the colonised is partly realised by the emergence of scientific racism which is backed up by and feeds into culturalised ideas of modernity and enlightenment. As a result, intelligible Europeanness becomes racialised as white (see for example Bhambra 2007: 120ff; El-Tayeb 2001; Gilman 1985; Gilroy 1993; Stoler 1995: 16; Wright 2004).

The question of home and belonging is an important one when considering transing the nation and transing gender together and in relation to processes of racialisation. Nael Bhanji is one of the few authors who theorises trans-nationalism in ways I have found converge with my argument and they have influenced my reading here. So, I will introduce their key points in some detail. Bhanji explicates that "trans-identified person[s] of color living in the diaspora" never can feel at home: "Forever in transit, we find ourselves living on the borders of homes" (Bhanji 2012: 159). A similar idea from a queer feminist perspective is expressed in Olumide Popoola's and Beldan Sezen's book Talking Home (Popoola and 
Sezen 1999). With their focus on home and longing for belonging accessed from a woman/queer of colour perspective, they open up an explicitly anti-racist and anti-migratist (queer) feminist approach to the delocalising effect of racism and migratism. They describe the failure to belong that is imposed by racism and migratism as the feeling of "never be[ing] whole', eternally searching, homeless and dispossessed (ibid.: 2).

"Home' is a location of dislocation and desire" (Bhanji 2012: 160), emphasises Bhanji, and they further express a deep frustration with many transgender studies approaches that are invested in metaphorical usages of border crossing, travelling and homecoming. Bhanji aims, in contrast, to think of 'trans politics' as critical towards a celebration of homecoming and easy belonging (ibid.: 157f) and criticises research on transgender that uses migration, home and transit as metaphors without reflecting on privilegings through citizenship, racism and nationality. Often these dimensions cannot even be thought of within the de-politicized, monolithic approaches to transgender.

Bhanji remarks that, inherent to the "politics of home", there is the attempt of normalisation and this becomes even more relevant when home is understood in a double sense of being at home in one's body (unambiguously and at any cost, as it is the case in many transgender narratives) and "being able to call a nation home" (ibid). Bhanji vehemently criticizes understandings of belonging to one side of the binary gender system as homecoming. "The journey home for the transsexual may come at the expense of a recognition that others are permanently dislocated from home - that they occupy the inhospitable territories in between", warns Bhanji, "the unhabitable "geographies of ambiguity"' (Bhanji 2012: 170).

I read the complexity of non-belonging to a gender binary as one aspect of a broader critique of understandings of transgender or transsexual that rely on ideas of unambiguous binary gendering. "We are all trans", argues Jack Halberstam provocatively (Halberstam 1994: 226): "[W]e have already surgically, technologically, and ideologically altered our bodies, our identities, ourselves" (Halberstam 1994: 215). Enke points in the same direction, criticising some self-appellations (in thoroughly critical intention) as 'cisgender' and 
underlines that they imply a re-essentialisation of gendering. For that matter, Enke refers to Simone de Beauvoir's statement "One is not born, but rather becomes, a woman" (Enke 2012b: 1; Beauvoir 2010: 293). The definition of 'cis-' as non-transition does not allow us to understand gender as always already a process of becoming, argues Enke (ibid.). This is related to Monique Wittig's conceptualisation of lesbians as outside of the category of women (Wittig 1993). In Wittig's thinking, lesbians are not women, in part, because they are not giving energy or labour (reproductive or affective) to, or are not in the service of, men. "It is the refusal of the economic, ideological, and political power of men" (Wittig 1993: 105), that puts lesbians outside of the category of women.

Halberstam points out that some trans concepts re-essentialise lesbians, dykes and butches and fix them in the binary category of 'women' (Halberstam 1998: 173). Following Halberstam here, I oppose the idea that lesbians or dykes are necessarily non-trans and therefore 'cis', and advocate an understanding of transgender that can embrace certain lesbian and dyke positionings. Obviously, not every conceptualization and self-construction of lesbians and dykes transes binary gendering, but this is paradoxically also true, as for example Halberstam and Bhanji show, for many conceptualizations of transgender. My reliance on 'trans_feminist' embraces, therefore, feminist knowledge productions that politicize going beyond gender in a feminist, power-sensitive way. Many (but of course not all) lesbian feminist and queer feminist politics and knowledge productions trans gender in specific ways and deconstruct essentialised ideas of gender binaries. With this, they enable in many dimensions a going beyond gendering and politicise the fact that many queer, lesbian and dyke feminist positionings cannot be at home in one fixed and pre-existing gendered category. In my understanding they are, therefore, not 'cis' and this idea challenges the meaning of 'cis' fundamentally.

With this in mind, it becomes clear that we need to conceptualise differences between trans- and cis- gender in ways that do not only reproduce a simple binary. I agree with interventions in simplified trans- and cisgender concepts, but I think it is necessary to distinguish the process of transing gender, that constructs, ascribes and stabilizes over time 
intelligible gender ("One is not born, but rather becomes, a woman"; emphasis mine), from the process of transing gender, that constructs persons who were, for example, ascribed as female at birth as beyond intelligible binary gendering, that transes them in the sense of making them unreadable within the possibilities of reading that are framed by binary gendering in the present. In my intervention, I aim to problematize the fact that not all notions of transgender are critical of gender binaries and heteronormativity - some reproduce gender binaries and heteronormativity - and not all border crossings produce subjects opposed to nationalism. "A heightened awareness of national boundaries, notions of belonging, and diasporic positionings does not preclude participation in nationalisms, fundamentalisms, and the like; in fact, such awareness may often facilitate them", asserts Puar (1998: 408).

Brought together with the thoughts on passing that I discussed earlier in this paper, one can say that passing as unambiguously gendered or racialised is not always a way of deconstructing relations of discrimination. On the contrary, some passing strategies do stabilize binary possibilities of legibility of social positionings. Yet, passing is sometimes essential for the survival of discriminated persons and can be therefore a strategy of resistance (Ahmed 1999b; Fütty 2010).

Passing can fail from many positionings and/or within specific contexts or constellations. It can become fundamentally impossible within conventionalized habits of perceiving. The impossibility of passing, the impossibility of being read as privileged in relation to certain power relations, poses a specific risk. This does not mean that persons who can pass are not in danger (on the contrary, passing is a precarious situation, see Fütty 2010: 67), but that not being able to pass is risky and precarious in a very specific way. It means that passing cannot be used as a strategy of resistance. Thus, a potential instrument to protect oneself from violence, discrimination and harm is not available.

Deconstructing gendering and national belonging can be grasped more productively, as I have tried to show, when we put into critical dialogue the insights from different schools of thought that seem often at odds with each other. Most importantly, it becomes clear that 
Western constructions of the entanglement of binary gender and nation are always racialised, as most explicitly queer and trans of color critiques show (see for example Bhanji 2012; El-Tayeb 2011; Haritaworn 2012a). Consequently, existing currents in feminist, postcolonial, queer and trans studies have to be increasingly crossed over and thought about in relation to each other. The following is an analysis of 'transnationalism' that relies on such a crossing over.

\section{Part II: Transnationalism}

If one of transnational feminism's projects is to go beyond the national, to criticize the stabilization of nations and nationality as 'natural' entities and to fight nationalism, might the term 'transnationalism' thus be misleading, carrying 'nationalism' within it (and maybe not only on a terminological level)? I do not suggest we replace the conventionalised term, but rather play around with different dimensions of meaning in order to interconnect transnational feminist and transgender feminist approaches, redefine the work of transing in the term, question their reliance on categories and intervene with help of their insights in reproductions of nationalism.

To do so, I analyse the following phenomena of transnationalism in relation to each other. First, I turn to transnationalism as in 'transgender nationalism' and show how it relies on the reproduction of binary gendering and the exertion of racism. As a second step, I discuss transnationalism as in 'cross-border-nationalism' that is too rooted in practising racism and reproducing hetero and binary gendered norms. In my readings of the examples, I juggle the concepts of passing/being read, transing and performativity which I have introduced above and aim to intervene in the logics of minority nationalisms and the idea that co-optation by majority nationalisms is a desirable goal on the way to belonging "without complication to a normative social sphere" (Aizura 2006: 290)

Jin Haritaworn criticises the tendency of white transgender and genderqueer persons to reproduce belonging through racist understandings of nation (Haritaworn 2012a: 12). Haritaworn describes this as a form of 'transgender nationalism' borrowing from Puar's 
concept of 'homonationalism' (Puar 2007). Hetero norms of gender and kinship are entangled with the reproduction of racialising and nationalizing norms (ibid.: 30 ). In a similar move, Aren Aizura (2006) questions the appropriation of nationalist 'politics of home' by white transsexuals ${ }^{x}$ in an Australian context, who reproduce normative white, heterogendered and capitalist citizenship in order to construct themselves as 'normal' Australian citizens who are entitled to rights like (hetero-)marriage and the founding of a nuclear family. Aizura criticizes the practices of white, (paradoxically) unambiguously gendered trans persons to inscribe themselves into the nationalist mainstream. This is based on a phantasy that functions to depoliticize one's own social positioning: trans persons become unambiguously gendered men or women and legitimize themselves in acting as nationalist, racist and heteronormative as other white cisgendered Australians (ibid.: 299). This is a strategy that can be called 'transnationalism', a rather different way of thinking the term than it is usually the case, when it is used as talking about solidarities beyond national boundaries.

Similar cases of transnationalism recently went viral in social media. In 2015 , the internet platform BuzzFeed published two stories, within days of each other, of transgender persons serving in the military. On January $19^{\text {th }}$, the story of Hannah Winterbourne, Captain in the British army, was issued under the title "Meet The First Transgender Officer In The British Army" ${ }^{\text {"xi }}$ and, on February $3^{\text {rd }}$, the story of 'Shachar' followed with the stunningly similar title "Meet Israel's First Out Transgender Military Officer"xii.

The British case is subtitled with "Captain Hannah Winterbourne decided to transition while serving in Afghanistan" and, while there is no hint that, for Winterbourne, 'realness' in gendered terms is connected to serving in the army as a woman, the rhetoric reproduces the narrative of a white, Western person finding their 'real' self during a colonial mission. Moreover, we are told in another article that the British army is a "fantastic employer for trans soldiers" military, one that relies on presenting the organization as progressive and open-minded. This helps to redirect the public's attention from the British implication in wars and 
(neo)colonialist missions abroad, a strategy that can be analysed under the term 'pinkwashing' (Puar 2013). Pinkwashing, a state practice that is made possible by homonationalism, is "the cynical promotion of LGBT bodies as representative of [...] democracy" (ibid.: 338). Puar and others use the term mostly in relation to Israel, but it becomes clear, as with the example of the British case, that it is a broader strategy of Western nationalism.

In the story of the Israeli officer, pinkwashing is also prominent but the focus of the article lies less on the narrative of finding oneself during a colonial mission than on the reproduction of binary gendering. 'Shachar', the Israeli transgender soldier, is quoted as saying: "For me, serving in the army and being recognized for who I really am by my fellow soldiers made me feel like a real man for the first time in my life. It made me feel like myself". ${ }^{\text {iv }}$ Here, it becomes clear that 'realness' in terms of gender identity is connected to nationalism, in this case to a heavily militarized form of nationalism that enables settler colonialism. Interestingly, serving in the army in Israel is not at all restricted to men, so it is not necessary to become a man in order to fulfil nationalism to such an extended degree. Thus, becoming a 'real man' here with the help of the recognition of the 'fellow soldiers' means simply being recognized by the nation state as serving it as a man; it means a nationalist celebrating of the possibility that a nation state not only does not care about having transgendered people serving in the military, but enables (properly binary gendered) transgendered persons to be a full part of the nationalist colonial project. The recognition of binary gendered 'realness' is one of the rewards that comes with defining and defending a home $^{\mathrm{xv}}$ through nationalism and settler colonialism.

Through my readings of theories and media examples so far, I have been trying to show that processes of mis/reading, passing and ascribing are complicated and analyses have to achieve a high level of complexity to deconstruct specific intersectional discriminations, privilegings, power relations and processes of normalisation and to address them in specific politics. 
Building on these considerations, I aim to bring together the theorisation of ascriptions, nationalist self-assurances and performative reproductions of gendering, racialization and national belonging in a phenomenon that can be named as transnationalism, as in 'cross-border-nationalism'. ${ }^{\text {xi }}$ I argue that this is based on similar strategies as the cases of transgender nationalism that I discuss above: on the reproduction of binary gendering and the exertion of racism. The readings of the following example are informed by the intersectional conceptualisations of transing, passing and mis/reading that I elaborate earlier in this article.

What happens if white (groups of) persons are being read as non-white? What happens for example, if (groups of) persons who consider themselves as being white Romanians, are being read in Western European contexts as Roma? Is this ascription antiromaist? And if so, for whom? For those who define themselves as white Romanians, or for the Roma? Or for both?

In 2009 and again in 2011 the fascist Romanian party Noua Dreaptă launched a poster campaign in Italy. On the posters, one can see two photos with Italian text ${ }^{x v i i}$. In my reading, the photo on the left side is meant to represent a 'Roma' family while the one on the right side represents a (hetero-reprogendered) 'Romanian' family. With this contrasting juxtaposition, a strong differentiation is produced. Under the right photo there is the word "romeni" (Italian for Romanians) and, under the left, the Italian antiromaist word for 'Roma', followed by "rom" in brackets (the Italian word for 'Roma'). Below the two images, one can read the demand, "Notate la differenza!" (Notice the difference!), and then the sentence, "Sono due popoli dissimili!" (They are two different/dissimilar people!"). The 'Roma family' is represented as dressed colourfully and arranged as a 'chaotic' and open group in front of a fence in the streets. The 'Romanian family' is draped in a photo studio setting, all dressed in white shirts or blouses and grouped in a closed arrangement. In my reading the latter are blond, much blonder than my own image of family belonging and Romanianness would ever suggest. The ones who are supposed to be recognized as Romanians are constructed as white through visualized representations of skin and hair colour as well as through clothing. 
It is about representing intelligible Europeanization and, even more, intelligible MiddleEuropeanization. The 'Roma family' is constructed in opposition to this as non-white. With the construction of the 'Romanian family', a middle European norm of family is reproduced. This is realized via the ordered grouping of the 'Romanian family' in contrast to the disorder of the construction of the 'Roma family' and the relatable unambiguous representation of kinship, age, number of persons, and gender. The norming of whiteness gets entangled here with the norming of binary hetero- and repronormativity: in my own reading the 'Romanian family' is constructed as consisting of father, mother and three children, while on the other photo the repro-structure remains much less clear. xviii $^{\text {in }}$

Noua Dreaptă's posters react to a broader disposition in Romania and in Romanian migrant groups in Western Europe. There is an omnipresent readiness to complain about the fact that, in Western European contexts, 'Romanian' and 'Roma' get confounded. Therefore, the 'Romanians' request a differentiation between these two terms that are constructed as mutually exclusive in hegemonic Romanian discourse. There are, for example, attempts in Romania and in the EU to enforce the official replacement of the appellation 'Roma' with the antiromaist word, in order to prevent confusing it with 'Romanian'. Thus, in 2010, the Romanian president Traian Băsescu is cited as explaining that the request for differentiating between the two categories was for "protecting the Romanians in gypsyphobic [sic!] regions, as the bad treatment and negative discrimination of Roma could affect in an unjustified [sic!] way Romanians too."xix

With this statement, Băsescu externalises antiromaism and locates it outside of Romania. At the same time, he constructs antiromaism as something that can affect Romanians in an 'unjustified' way. This implies that, in his opinion, there is a group of persons that can be justifiably affected by antiromaism. However, in Romania the Roma are exposed to immense discriminations, explicates Jennifer Tanaka (1995). Moreover, there are constant attempts from the white Romanians to distinguish themselves from the Roma. ${ }^{x x}$ Anda Nicolae Vladu and Malte Kleinschmidt show, with their analyses of Romanian fiction from the $19^{\text {th }}$ century and recent media debates, that antiromaism is inscribed in the 
narratives that have founded the Romanian nation from its beginnings and have been reproduced constantly until today (Nicolae Vladu and Kleinschmidt 2009). Anikó Imre asserts, in relation to Hungary, that the white Christian population of Eastern Europe has decided to distance itself from the Roma in order to mask the insecurity about their own identity (Imre 2005: 86): "With the collapse of socialism East Europeans have suddenly awakened from their relative imprisonment [...] and found their national boundaries vulnerable for influences from the world" (ibid.: 81). According to Imre, one reason for the ongoing attempts of the Eastern European, white, Christian population to distinguish themselves from the Roma is the fact that Western media does not differentiate between the two different cultures: "[Eastern Europeans] are treated as 'Gypsies' by the Western Media" (ibid.: 86). Imre uses the antiromaist appellation and pejorative (Hornscheidt 2011) 'gypsies' repeatedly in her text. Moreover, she conducts a problematic twist in her argument: in her opinion, the antiromaism of the Eastern European mainstream population is not responsible for their vehement delineation from the Roma, but the fact that they are treated like Roma in Western European discourses and because their cultures get conflated. I do not agree but, instead, propose that antiromaism provides the opportunity for white Christian Eastern Europeans - the aspirants of (Western) European participation (Boatcă 2013) - to demonstrate their whiteness and to construct themselves as intelligibly European (Boatcă 2006: 99).

There is no doubt that Western European discourses that construct Romanians and Romania are discriminating. Following Maria Todorova (2009), Manuela Botacă understands the construction of Southeastern Europe as interstage between the Orient and Occident: "Moreover, Southeastern Europe's proximity to Asia and its Ottoman cultural legacy located it halfway between East and West, thus giving it a condition of semi-Oriental, semi-civilized, semi-developed" (Boatcă 2013: 6). It becomes evident that the European separation has been established for centuries and is not rooted in the relatively short period of state socialism and the construction of the Eastern bloc (Boatcă 2006, 2013). Eurocentric assumptions of backwardness are transferred to Southeastern Europe - it is constructed as 
“Europe's incomplete Self” (Boatcă 2013) by Orientalist discourses (Said 2003), as 'epigonal Europe' (Boatcă 2013), trying to prove its proper Europeanness but constantly failing. Racism, nationalism and fascism can be used as strategies to construct intelligible Euopeanness; "the aspiration to Europeanness" (Boatcă 2013) is legitimized through racist practices of the aspirants. In a migration context, this is realized through a phenomenon that I call transnationalism or cross-border-nationalism.

(Groups of) Persons who are constructed as Romanians in Western European contexts are, without doubt, discriminated against by migratism (Tudor 2014, 2016) and Romania gets devalued chauvinistically in many dimensions (Boatcă 2006, 2013; Tlostanova 2012). In recent nationalist debates in Western Europe, the terms 'Romanians' and 'Roma' are indeed mostly used as synonyms (Nicolae Vladu and Kleinschmidt 2009). However, through the analyses of my example, it becomes clear that the attempt to 'correct' a 'misreading' of one's own social positioning and to persist on controlling the representation of oneself is not automatically emancipatory, but can be racist and self-privileging. With their racist delineation against the Roma, the white Romanians try to annul their own marginalisation within a system of hierarchies in Europe.

Building on Puar's conceptualization of homonationalism, this phenomenon, which of course does not occur in Romanian migrant communities only, can be named as 'crossborder-nationalism': the attempts of a migratised group to assimilate to the nationalist mainstream of their country of 'origin'. Moreover, transnationalism relies on invoking racist nationalisms as the supra-national commonality of Europeanness and self-construction as intelligibly European. In my example, fascist supra-nationalism allows for a Romanian fascist group, with the help of an Italian fascist group (Fuerza Nuova), to launch an antiromaist poster campaign in Italy to secure the borders of intelligible Europeanization. ${ }^{x \times i}$

Theorists such as Fatima El-Tayeb formulate critiques of these efforts to belong to the norm in European contexts. There is a tendency amongst white non-migrant gays, bisexuals and lesbians to want to be recognized, to be 'normal' and to dissolve as unmarked within the nation. El-Tayeb calls this adoption and hyper-pronunciation of conservative ideas, 
the preaching of traditional values and the insistence on normality 'solidarisation with the mainstream' (El-Tayeb 2003: 132). Instead of practising solidarity with the marginalized and deconstructing mechanisms of marginalization, this attitude reproduces racist, sexist and neo-liberal exclusions (ibid.: 134).

The logics of homonationalism can also be applied to cross-border-nationalism and a similar process is discussed by Puar herself. In the US, after 9/11, there were a series of hate crime murders against Sikhs, as they were read as presumed 'Muslim terrorists' (Puar 2007: 166). These hate crimes were answered by an educational campaign with the goal of self-representing Sikhs as a group who personify a form of "proper American heteromasculinity“ (ibid.: 167) and could therefore be distinguished from the perverted "terrorist bodies" - the 'real Muslims' (ibid.). Puar notices that the attempts of delineation are rooted in the idea that the white Christian majority would be interested in (perceiving) the difference between two groups that both are constructed as non-white. Through a desolidarisation with Muslims, some Sikhs tried to inscribe themselves into the US American nation. But this undertaking cannot succeed, underlines Puar (ibid.).

Applied to the violent self-construction of white Romanians as Not-Roma at the expense of a re-essentialisation of Roma as 'real Roma', the question remains whether, in this context and constellation, the undertaking can actually succeed? Is it possible for white Romanians to wrench recognition from white Western Europeans in order to be perceived as intelligible Europeans? The situation that is discussed in Puar's text is different from my example here and the difference lies in the self-construction of the group that seeks to be read 'correctly'. In the case of the Romanians, the self-construction is rooted in whiteness, Christianity and Europeanness. In the example of the Sikhs, this is not the case. What connects both examples is the similar process of de-solidarisation and also the overemphasis of repro- and hetero gender norms in order to secure a place within a nondeviant part of the nation or Europe.

According to Lann Hornscheidt's conceptualisation of pejorisation (Hornscheidt 2011), it can be argued that the ascription as Roma of white Romanians is discriminatory - 
however, not against the white Romanians, but against the Roma. A straight cis-woman who gets appellated as 'lesbian', Hornscheidt argues, can only perceive this as a hurt if she reproduces straightness as desirable norm and being a lesbian as something negative. Thus, perceiving 'lesbian' as a slur is harmful for lesbians and not for straight women (Hornscheidt 2011: 37).

Applied to the ascription as Roma, this is also fundamentally true for the appellation: to perceive it as a harm to be named as 'Roma', to understand the appellation as a slur and the misreading as Roma as wrongful, reproduces antiromaism. I follow Hornscheidt's analysis that straight women who feel wrongly interpolated as lesbians reproduce in this idea of wrongfulness lesbophobia and heteronormative gendering. In order to challenge Hornscheidt's concept, however, one could ask: how many performative repetitions of the appellation 'lesbian' does it take for a 'straight cis-woman' to un-become a 'straight ciswoman' and to be constructed discursively as a lesbian? Or does she then become a straight woman who gets discriminated like a 'real lesbian', but does not become a 'real lesbian'? Let me refer back to my own example of being 'misread' as a Muslim migrant adolescent boy: How many readings does it take to become that Muslim migratised boy I am mistaken for? In relation to my example of cross-border-nationalism one could ask if 'white Romanians' can become 'Roma' through repeated performative appellations as 'Roma'? Does this happen, and if so, after how many repetitions? For whom does this happen? The white Western Europeans (who are the appellators), or for the de-whitened Romanians (who get appellated) or for the Roma (who become abjects)?

Especially in countries like Italy and Spain where many 'guest workers' from Romania live, there occur repeated incidents such as pogroms against Romanian Roma but also against white Romanians (for example rapes and murders of Romanian women that are only faint-heartedly prosecuted) $)^{x \times i i}$. It is not traceable if these persons are all murdered or attacked for antiromaist reasons. And, if this was the case, would the fact of a white Romanian being killed by antiromaism be such an unambiguous ascription of being Roma, that in death the murdered becomes Roma? Or is this 'only' mistaken identity? Why do 
killings appear to be more unambiguous manners of death and more valid ascriptions than 'slow deaths' (Berlant 2007), manners of death that are not recognized as such? Which roles do intersectional power relations like sexism, migratism and racism play in relation to the incidents, slow deaths and killings?

All of these question could be answered in various dimensions. Of course, I do not pose them here to find out the exact moment and the exact situation in which a person becomes what they are ascribed, but to raise attention to the idea that processes of becoming and performative ascriptions have a complex connection. In other words: I do not pose these questions because I want to find unambiguous answers, but because I want to provoke a reflection on how discrimination and power relations construct and fix persons or their social positionings through performative acts. Following Ahmed, I argue that ascriptions of non-whiteness do not automatically mean to become non-white and ascriptions of masculinity do not automatically mean to become a man. Moreover, as I have stated above, processes of gendering and racialization do not function in parallel ways and transing gender is not the same as deconstructing racialization. So, performative processes of becoming through repeated interpellations are intersectional in many dimensions but might work in contradictory ways. Ahmed substantiates this with the "reopening or restaging of a fractured history of identifications" (Ahmed 1999b: 93).

This means that Roma who are read as Roma have a history of self-identification and identification through others that is formed by the discrimination by antiromaism, while white Romanians have a history of self-identification and identification through others that is formed by the privileging by antiromaism. Roma - in contrast to white Romanians - do not have the possibility to construct themselves as white through a mixture of racist, nationalist, gendered and sexualized norms. The self-construction of the white Romanian migrants shows that neither crossing borders nor the status as migrant automatically creates a critical attitude or the rejection of national belonging, nationalism or Eurocentrism. "[T]here is a distinction between transgressing ideologies of nationhood and transversing national boundaries“, emphasises Puar (1998: 410). 


\section{Conclusion:}

At this point, I do not want to come up with a 'solution' and do not want to offer ultimate answers to my questions, but, instead, direct attention to the political concept of solidarity. If straight women showed solidarity with lesbians and reflected their own privileging in relation to heteronormativity as well as intervened in effects of sexism, lesbo-, queer- and transphobia, if they turned self-reflexively and in solidarity towards political alliances instead of perceiving being named as 'lesbian' as offensive, the circle of reproducing gendered and sexual normalisations would have been interrupted for a moment. Likewise white Romanians, who are being read as 'Roma', could put their energies in alliances based on solidarity against antiromaism, migratism, racism and nationalism, without victimizing themselves and forgetting about their privileging in relation to Roma.

In my own example, being 'read' might produce solidarities with 'others' whose 'risks' I do not claim as my own. While I have a history of being read as a boy and/or as gender deviant woman and_or as dyke and_or as transperson, and while I have a history of being migratised - ascribed with migration - in Western contexts, I do not have a history of selfidentification and identification through others as Muslim or PoC beyond some reading incidents. Solidarity might mean reflecting and acknowledging the shared and divided histories of being constructed as migrants in Western contexts while taking responsibility for privilegings that come with a history of self-identification and identification through others (see Ahmed 1999b: 93) as white.

Binary gendering, racialization and nation are entangled but they do not function in parallel ways. While I think it is politically necessary to intervene in and oppose all forms of European nationalism and deconstruct the automatized nexus of home and nation, I do not per se criticise the desire (some) trans persons might have to belong to one side of the gender binary. My critique focuses on the mobilisation of nationalist, sexist and racist logics for achieving the goal of 'being at home' in a binary gender category (see Aizura 2006, Bhanji 2012). 
Beyond these thoughts, I do not render readings, misreadings, ascriptions and the related discriminations as absolute. Every reading is a misreading. Not every discrimination is visible and perceivable for others. Not every story and history reveals itself and is legible or intelligible (Haritaworn 2012b). As Ahmed puts it, it is not about actual visibilities, but about stories and histories of positioning and being positioned (Ahmed 1999b), about sedimentations of harm, vulnerabilities and complex forms of being exposed.

One possibility for translating my specific analyses into forms of activism is to start from power relations which construct social positionings through movements, shiftings, cross-fadings and contradictory discourses, and not from fixed categories. As nationalism is a paradigm of (post)colonial processes of normalisation on the level of nation states, often the unquestioned dispositive condition of social, constant conscious and unconscious renationalisations cannot be avoided and have to be deconstructed in ongoing processes. The translation of this insight into responsible politics asks for forms of transnational alliances which reflect and deconstruct power relations like antiromaism, migratism, sexism, dykeand transphobia and colonial racism in their specific and spatial-temporary contexts and with their shifting and contradictory effects. Resistance also means to resist nationalist logics and co-optations by the mainstream. In these alliances, movements and struggles, different forms of risks, vulnerabilities and exposure exist that are defined by, for example, racialisation, citizenship, gendering, religion and ability. They are constitutive of the very meaning of the struggles and movements and define what they can be, what they want and what they can want.

References:

Ahmed, Sara (1999a): "Home and Away. Narratives of Migration and Estrangement". In: International Journal of Cultural Studies. 2 (3), S. 329-347.

Ahmed, Sara (1999b): "'She'll Wake up One of These Days and Find She's Turned into a Nigger'. Passing Through Hybridity". In: Theory, Culture \& Society. 16 (2), pp. 87-106.

Aizura, Aren Z. (2006): "Of Borders and Homes: The Imaginary Community of (trans) Sexual Citizenship". In: Inter-Asia Cultural Studies. 7 (2), pp. 289-309.

Alexander, M. Jacqui; Mohanty, Chandra Talpade (1997): Feminist Genealogies, Colonial Legacies, Democratic Futures. London: Routledge. 
Al-Ali, Nadje (2009): "Up Against Conceptual Frameworks: Post-Orientalism, Occidentalism and Presentations of the Self". In: Secularism, Gender and the State in the Middle East: The Egyptian Women's Movement. Cambridge University, pp. 19-50.

Bachmann, Ingeborg (1995): „Todesarten“-Projekt. Kritische Ausgabe. München, Zürich: Piper.

Beauvoir, Simone de (2010): The Second Sex. London: Vintage Books.

Berlant, Lauren (2007): "Slow Death (Sovereignty, Obesity, Lateral Agency)". In: Critical Inquiry. 33 (4), pp. 754-780.

Bhambra, Gurminder K. (2007): Rethinking Modernity: Postcolonialism and the Sociological Imagination. Basingstoke, Hampshire; New York: Palgrave.

Bhanji, Nael (2012): "TRANS/SCRIPTIONS: Homing Desires, (Trans)sexual Citizenship and Racialized Bodies". In: Cotten, Trystan T. (Ed.) Transgender Migrations. The Bodies, Borders, and Politics of Transition. New York: Routledge, pp. 157-175.

Boatcă, Manuela (2006): "No Race to the Swift. Negotiating Racial Identity in Past and Present Eastern Europe". In: Human Architecture: Journal of the Sociology of Self-Knowledge. V (1), pp. 91-104.

Boatcă, Manuela (2013): "Multiple Europes and the Politics of Difference Within". In: Worlds \& Knowledges Otherwise (WKO). Uneasy Postcolonialisms. 3 (3), online: https://globalstudies.trinity.duke.edu/wpcontent/themes/cgsh/materials/WKO/v3d3_Boatca2.pdf [20.01.2014].

Brah, Avtar (1996): Cartographies of Diaspora. Contesting Identities. London, New York: Routledge.

Butler, Judith (1993): Bodies That Matter. On the Discursive Limits of "Sex“. New York: Routledge.

Butler, Judith (1993): "Passing, Queering: Nella Larsen's Psychoanalytic Challenge". In: Bodies That Matter. On the Discursive Limits of „Sex“. New York: Routledge, pp. 167-186.

Butler, Judith (2007): Gender Trouble. Feminism and the Subversion of Identity. New York: Routledge.

Butler, Judith (2012): "'What shall we do without exile?"'. In: Parting Ways. Jewishness and the Critique of Zionism. New York: Columbia University, pp. 205-224.

Campt, Tina (2011): "what's the 'trans' and where's the 'national' in transnational feminist practice? a response". In: Feminist Review, pp. e130-e135.

Cotten, Trystan T. (Ed.) (2012): Transgender Migrations. The Bodies, Borders, and Politics of Transition. New York: Routledge.

Crenshaw, Kimberle (1991): "Mapping the Margins: Intersectionality, Identity Politics, and Violence against Women of Color". In: Stanford Law Review. 43 (6), pp. 1241-1299.

El-Tayeb, Fatima (1999): ",Blood Is a Very Special Juice': Racialized Bodies and Citizenship in Twentieth-Century Germany". In: International Review of Social History. 44 (Supplement S7), pp. 149-169.

El-Tayeb, Fatima (2001): Schwarze Deutsche. Der Diskurs um „Rasse“ und nationale Identität 18901933. Frankfurt a.M., New York: Campus.

El-Tayeb, Fatima (2003): "Begrenzte Horizonte. Queer Identity in der Festung Europa". In: Steyerl, Hito; Gutiérrez Rodríguez, Encarnación (Eds.): Spricht die Subalterne deutsch? Migration und postkoloniale Kritik. Münster: Unrast, pp. 129-145.

El-Tayeb, Fatima (2011): European Others. Queering Ethnicity in Postnational Europe. Minneapolis, London: University of Minnesota.

Enke, Anne Finn (Ed.) (2012a): Transfeminist Perspectives in and Beyond Transgender and Gender Studies. Philadelphia: Temple University.

Enke, Anne Finn (2012b): "Introduction: Transfeminist Perspectives". In: Transfeminist Perspectives in and Beyond Transgender and Gender Studies. Philadelphia: Temple University, pp. 1-15. 
Enke, Anne Finn (2012c): "The Education of Little Cis: Cisgender and the Discipline of Opposing Bodies". In: Transfeminist Perspectives in and Beyond Transgender and Gender Studies. Philadelphia: Temple University, pp. 60-77.

Fitzgerald, David (2004): “Beyond 'Transnationalism': Mexican Hometown Politics at an American Labor Union". In: Ethnic and Racial Studies 27(2), pp. 228-47

Frankenberg, Ruth; Mani, Lata (1993): "Crosscurrents, Crosstalk: Race, ,Postcoloniality and the Politics of Location". In: Cultural Studies. 7 (2), pp. 292-310.

Fütty, Jules Tamàs (2010): "Challenges Posed by Transgender - Passing Within Ambiguities and Interrelations". In: GJSS. 7 (2), pp. 57-75.

Gilman, Sander L. (1985): "Black Bodies, White Bodies: Toward an Iconography of Female Sexuality in Late Nineteenth-Century Art, Medicine, and Literature". In: Critical Inquiry. 12 (1), pp. 204242.

Gilroy, Paul (1993): The Black Atlantic. Modernity and Double Consciousness. London, New York: Verso.

Gopinath, Gayatri (2003): "Nostalgia, Desire, Diaspora: South Asian Sexualities in Motion". In: Braziel, Jana Evans; Mannur, Anita (Eds.): Theorizing Diaspora. A Reader. Malden: Blackwell, pp. 261-279.

Grewal, Inderpal (2005): Transnational America. Feminisms, Diasporas, Neoliberalisms. Durham, London: Duke University.

Grewal, Inderpal (2006): "Autobiographic Subjects and Diasporic Locations: Meatless Days and Borderlands". In: Grewal, Inderpal; Kaplan, Caren (Eds.) Scattered Hegemonies. Postmodernity and Transnational Feminist Practices. Minneapolis: University of Minnesota, pp. 231-254.

Grewal, Inderpal; Kaplan, Caren (2006): "Introduction: Transnational Feminist Practices and Questions of Postmodernity". In: Scattered Hegemonies. Postmodernity and Transnational Feminist Practices. Minneapolis: University of Minnesota, pp. 1-33.

Halberstam, Judith Jack (1994): "F2M: The Making of Female Masculinity". In: Doan, Laura (Ed.): The Lesbian Postmodern. New York: Columbia University, pp. 210-228.

Halberstam, Judith Jack (1998): Female Masculinity. Durham, London: Duke University.

Hall, Stuart (2006): "The West and the Rest. Discourse and Power.". In: Maaka, Roger C.A.; Chris Andersen (Eds.) The Indigenous Experience: Global Perspectives. Toronto: Canadian Scholars', pp. 165-173.

Haritaworn, Jin (2008): "Shifting Positionalities: Empirical Reflections on a Queer/Trans of Colour Methodology". In: Sociological Research Online. 13 (1), http://www.socresonline.org.uk/13/1/13.html

Haritaworn, Jin (2012a): "Colorful Bodies in the Multikulti Metropolis: Vitality, Victimology and Transgressive Citizenship in Berlin". In: Cotten, Trystan T. (Ed.) Transgender Migrations. The Bodies, Borders, and Politics of Transition. New York: Routledge, pp. 11-31.

Haritaworn, Jin (2012b): "Viel zu viel und längst nicht genug: Queer-of-Colour-Politiken und nachhaltige Communities". In: freitext - Kultur und Gesellschaftsmagazin. 10 (20), pp. 46-52.

Haritaworn, Jinthana (2012c): The Biopolitics of Mixing. Thai Multiracialities and Haunted Ascendancies. Farnham (Surrey): Ashgate Publishing.

Herr, Ranjoo Seodu (2014): "Reclaiming Third World Feminism: or Why Transnational Feminism Needs Third World Feminism". In: Meridians: feminism, race, transnationalism. 12 (1), pp. 130.

Hornscheidt, Lann (2011): "Pejorisierung - ein konstruktivistisches Konzept zur Analyse von Beschimpfungspraktiken". In: Hornscheidt, Lann; Jana, Ines; Acke, Hanna (Eds.) Schimpfwörter - Beschimpfungen - Pejorisierungen. Wie in Sprache Macht und Identitäten verhandelt werden. Frankfurt a.M.: Brandes \& Apsel, pp. 15-45. 
Ignatiev, Noel (1995): How the Irish Became White. New York: Routledge.

Imre, Anikó (2005): "Whiteness in Post-Socialist Eastern Europe: The Time of the Gypsies, the End of Race". In: López, Alfred J. (Ed.) Postcolonial Whiteness. A Critical Reader on Race and Empire. Albany: State University of New York, pp. 79-102.

Kilomba, Grada (2008): Plantation Memories. Episodes of Everyday Racism. Münster: Unrast.

Lewis, Gail (2013): "Unsafe Travel: Experiencing Intersectionality and Feminist Displacements". In: Signs. 38 (4), pp. 869-892, 10.1086/669609.

Mama, Amina (2004): "Demythologising Gender in Development: Feminist Studies in African Contexts". In: IDS Bulletin. 35 (4), pp. 121-124.

Mama, Amina (2011): "what does it mean to do feminist research in African contexts?". In: Feminist Review. 2011 (S1), pp. e4-e20, 10.1057/fr.2011.22.

Mbembe, Achille (2003): "Necropolitics". In: Public Culture. 15 (1), pp. 11-40.

Mendoza, Breny (2002): "Transnational Feminisms in Question". In: Feminist Theory. 3 (3), pp. 295314.

Mohanty, Chandra Talpade (2003a): Feminism Without Borders. Decolonizing Theory, Practicing Solidarity. Durham, London: Duke University.

Mohanty, Chandra Talpade (2003b): "Genealogies of Community, Home, and Nation". In: Feminism Without Borders. Decolonizing Theory, Practicing Solidarity. Durham, London: Duke University.

Nicolae Vladu, Anda; Kleinschmidt, Malte (2009): "Von Zigeunern und Vampiren. ,Der Zigeuner' als das Andere des rumänischen Selbst". In: Markus End; Herold, Kathrin; Robel, Yvonne (Eds.) Antiziganistische Zustände. Zur Kritik eines allgegenwärtigen Ressentiments. Münster: Unrast pp. 204-232.

Noble, Bobby (2012): "Trans. Panic. Some Thoughts toward a Theory of Feminist Fundamentalism". In: Enke, Anne Finn (Ed.) Transfeminist Perspectives in and Beyond Transgender and Gender Studies. Philadelphia: Temple University, pp. 45-59.

Popoola, Olumide; Sezen, Beldan (Eds.) (1999): Talking Home. Heimat aus unserer eigenen Feder. Frauen of Color in Deutschland. Amsterdam: Blue Moon.

Pavlásek, Michal (2013): "Cross-Border Nationalism and Religious Fellowship. A Case Study of the Czech Protestant Community in Serbia". In: Radović, Srdjan (Eds.): Cultural Permeations: Anthropological Perspectives. Belgrade (Collection of Papers of Ethnographic Institute, Volume 28), pp. 195-207.

Puar, Jasbir K. (1998): "Transnational Sexualities: South Asian (Trans)nation(alism)s and Queer Diasporas". In: Eng, David L.; Hom, Alice Y. (Eds.): $Q$ \& A: Queer in Asian America. Philadelphia: Temple University, pp. 405-424.

Puar, Jasbir K. (2005): "Queer Times, Queer Assemblages". In: Social Text. 23 (3-4 84-85), pp. $121-$ 139.

Puar, Jasbir K. (2007): Terrorist Assemblages. Homonationalism in Queer Times. Durham, London: Duke University.

Puar, Jasbir K. (2012): ",I Would Rather Be a Cyborg Than a Goddess'. Becoming-Intersectional in Assemblage Theory". In: philoSOPHIA. 2 (1), pp. 49-66.

Puar, Jasbir K. (2013a): "Homonationalism As Assemblage: Viral Travels, Affective Sexualities". In: Jindal Global Law Review. 4 (2), pp. 23-43.

Puar, Jasbir K. (2013b): "Rethinking Homonationalism". In: International Journal of Middle East Studies. 45 , pp. 336-339.

Sangtin Writers Collective; Nagar, Richa (2006): Playing with Fire. Feminist Thought and Activism through Seven Lives in India. Minneapolis, London: Univ. of Minnesota. 
Sayegh, Ghiwa (2015): "Rethinking Intersections, Rethinking Contexts: Writing in Times of Dissent". In: Kohl: A Journal for Gender and Body Research. 1 (1), pp. 1-4.

Shohat, Ella (2001): "Introduction". In: Talking Visions. Multicultural Feminism in a Transnational Age. Cambridge: MIT Press, pp. 1-64.

Shohat, Ella (2002): "Area Studies, Gender Studies, and the Cartographies of Knowledge". In: Social Text 72. 20 (3), pp. 67-78.

Spade, Dean (2011): Normal Life. Administrative Violence, Critical Trans Politics, and the Limits of Law. Brooklyn, NY: South End.

Stoler, Ann Laura (1995): Race and the Education of Desire: Foucault's History of Sexuality and the Colonial Order of Things. Durham: Duke University Press.

Stryker, Susan; Currah, Paisley; Moore, Lisa Jean (2008): "Introduction: Trans-, Trans, or Transgender?". In: WSQ: Women's Studies Quarterly. 36 (3\&4), pp. 11-22.

Tlostanova, Madina (2012): "Postsocialist $\neq$ Postcolonial? On Post-Soviet Imaginary and Global Coloniality". In: Journal of Postcolonial Writing. 48 (2), pp. 130-142.

Todorova, Maria (2009): Imagining the Balkans. Oxford, New York: Oxford University.

Trinh, Thi Minh-ha (1989): Woman, Native, Other. Writing Postcoloniality and Feminism. Bloomington: Indiana University.

Trinh, Thi Minh-ha, (2010): Elsewhere, Within Here: Immigration, Refugeeism and the Boundary Event. New York: Routledge.

Tudor, Alyosxa (2014): from [al'manja] with love: Trans_feministische Positionierungen zu Rassismus und Migratismus. Frankfurt a.M.: Brandes \& Apsel.

Tudor, Alyosxa (2016): "Postcolonial Queer Europe(s): Transnational Feminist Epistemologies and the Differentiation of Racism and Migratism in Critical Knowledge Production". In: Lambda Nordica, Special issue on 'Postcolonial Queer Europe'. [forthcoming]

Wilson, Kalpana (2012): Race, Racism and Development: Interrogating History, Discourse and Practice. London, New York: Zed Books.

Wittig, Monique (1993): "One Is Not Born a Woman". In: Abelove, Henry; Barale, Michèle Aina; Halperin, David M. (Eds.) The Lesbian and Gay Studies Reader. New York: Routledge, pp . 103-109.

Wright, Michelle M. (2004): "The European and American Invention of the Black Other". In: Becoming Black. Creating Identity in the African Diaspora. Durham, London: Duke University.

Yuval-Davis, Nira (1993): "Gender and Nation.". In: Ethnic \& Racial Studies. 16 (4), pp. 621-632.

' Thanks to Clare Hemmings and Wendy Sigle for responses to earlier drafts and to the reviewers and editors of FR for their constructive engagement.

ii For different usages of 'transing' see for example Noble 2012; Stryker et al. 2008; Tudor 2014.

iii With my usage of 'intersectionality', I refer to Kimberle Crenshaw's original formulation (Crenshaw 1991), but follow also Gail Lewis who emphasises that the concept travels and has to be adapted to specific contexts. Lewis makes clear though, that the analysis of racism is not optional in intersectionality theories and criticises European adaptions of intersectionality that do not take racialisation and racism into account (Lewis 2013).

${ }^{\text {iv }}$ Autobiographical approaches can be one way to access the complexity of politicising positioning within power dynamics. For other autobiographical accounts that reflect on complex constructions of gendering, racialization, migratisation and belonging see for example Ahmed 1999b, Bhanji 2012; Haritaworn 2008.

$\checkmark$ I suggest to differentiate between social positionings and critical positionings. While former are processes of ascription and constructed by power relations, the latter are the politicisations of social positionings: politicised ways of making sense of processes of becoming through intersectional power relations. The possibility of inhabiting an intelligible social positioning is often fixed within rigid binary registers of belonging (man/woman; white/non-white etc.). My argument is that although social positioning can be thought as nonessential, but as constructed through performative processes and as effects of intersectional power relations, 
they should not be seen as the basis for political struggle. Rather it is the politicisation of social positionings critical positionings - that allows for (temporal, fragile and contradictory) solidarities, alliances and shared struggles (see Tudor 2014).

${ }^{\mathrm{vi}}$ Halberstam contextualizes this statement later on and withdraws it partly (Halberstam 1998: 173). I do not want to suggest that all persons trans gender in the same way, but following Enke (2012c) I think it is relevant to think gender always in terms of transing, as complex process of becoming and ascription.

vii ,Migratised' means being ascribed with migration, being constructed as migrant. The term was coined by Tudor 2014.

viii Migratism is the power relation that constructs migrants and ascribes migration as deviant position and nonmigration as the norm of Western societies. Migratism is often is a strategy of racism, but not all forms of migratism are racist. The term was coined and conceptualised by Tudor 2014

${ }^{\text {ix }}$ Gender and race do not work analogously and power relations that construct gender and race function not in a parallel way. Therefore deconstructions of gender and race can not be equated. For making sense of the ascription of in-betweeness in connection to racialization see for example Haritaworn's ,mixed race' approach (Haritaworn 2012c).

'Aizura subsumes ,transsexuals' and ,transgender' under the umbrella-term ,trans'. ,Transsexuals' is in his terminology an appellation for persons who undergo a physical transition with the goal to belong to one side of the binary gendering. However it is also a juridical and pathologising category and usages are not selfevident or universal, warns Aizura (2006: 291f).

${ }^{x i}$ www.buzzfeed.com/richardhjames/transgender-officer-in-the-british-army\#.qlq1KmYD2 [06.12.2015]. [19.08.15]. www.buzzfeed.com/sheerafrenkel/meet-israels-first-openly-transgender-military-officer\#.cpOVZPNxg [06.12.2015].

http://i100.independent.co.uk/article/meet-the-first-transgender-officer-in-the-british-army--xkwc5UzMje [19.08.15].

www.buzzfeed.com/sheerafrenkel/meet-israels-first-openly-transgender-military-officer\#.cpOVZPNxg

xv See Judith Butler's critique of Zionist homecoming and dissolving the Jewish diasporic condition through creating new dispossessions and a situation of war, exile and persecution for the Palestinians (Butler 2012).

Xvi The term 'cross-border nationalism' has been used before. See for example Fitzgerald 2004; Pavlásek 2013. For conceptualisations closest to my understanding, without necessarily using the term, see Gopinath 2003; Grewal 2005; Puar 1998.

xvii www.ziare.com/diaspora/romani-italia/afis-in-italia-rromii-si-romanii-sunt-doua-popoare-diferite-1138355 [18.09.2015].

xviii See also Nicolae Vladu and Kleinschmidt in relation to a TV spot that was launched by Noua Dreaptă in Italian TV (Nicolae Vladu and Kleinschmidt 2009: 224).

xix My translation. See diepresse.com/home/politik/eu/593686/Rumaenischer-Praesident-fuer-Zigeuner-stattRoma-; stirileprotv.ro/stiri/politic/romi-sau-tigani-un-deputat-pdl-propune-inlaturarea-acestei-confuzii.html; [all 18.09.2015].

xx Tanaka 1995: www.reocities.com/ patrin/rroma.htm [18.09.2015]. Tanaka uses from a positioning that is discriminated by antiromaism 'Rroma' with a double-r, to create an empowering self-appellation. She suggests to use the term in this spelling as critical positioning. I don't use the spelling suggested by Tanaka, as there were attempts in Romania to appropriate this critical positioning and use it for distinguishing Roma from Romanians. www.ziare.com/diaspora/romani-italia/afis-in-italia-rromii-si-romanii-sunt-doua-popoare-diferite-1138355 [18.09.2015].

xxii www.youtube.com/watch?v=FTHglfLsySk [18.09.2015]. 